\title{
A Possible New Pathogen of Group III Mycobacteria
}

\author{
By M. TSUKA MURA \\ The National Sanatorium Chubu Chest Hospital, Obu, Aichi, Japan \\ H. SHIMOIDE \\ The National Sanatorium Tokyo Chest Hospital, Kiyose, Tokyo, Japan \\ AND W. B. SHAEFER \\ National Jewish Hospital, Denver, Colorado, U.S.A.
}

(Received 9 December 1974; revised 24 January 1975)

\section{INTRODUCTION}

In the course of a co-operative study by eleven Japanese national chest hospitals on mycobacterioses due to mycobacteria other than Mycobacterium tuberculosis, a 56-year-old man was found to excrete a new group III mycobacterium. The organism was isolated on salicylate medium (Tsukamura, 1962) and identified as a new organism in 1968 in the research laboratory of the Chubu Chest Hospital. The man was a patient at the Tokyo Chest Hospital and had tuberculosis-like cavitary lesions in his lungs. Similar organisms were isolated twice in 1969 and thereafter were not evident until I973. In I973, the same organism was isolated from sputum by the use of a $p$-nitrobenzoic acid medium (Tsukamura \& Tsukamura, 1964) in July and September, and the patient died that same year of the lung disease. M. tuberculosis was not isolated throughout the period of observation.

\section{METHODS}

A total of seven strains isolated between 1968 to 1973 were studied. Identification was carried out as described previously (Tsukamura, I967a, 1969). Additional tests included lipid analysis using the method described by Marks, Jenkins \& Schaefer (I97I), and seroagglutination studies with the method described by Schaefer (1965).

\section{RESULTS AND DISCUSSION}

All seven strains showed similar biological and biochemical characters.

Morphology. Gram-positive, acid-fast rods ( 0.5 to $\mathrm{I} \cdot \mathrm{O}$ by 2 to $3 \mu \mathrm{m})$. Clumping or cordlike masses were not observed.

Biological characteristics. The organisms grew very slowly. Scant growth occurred on Ogawa egg medium and Löwenstein-Jensen medium after incubation at $37{ }^{\circ} \mathrm{C}$ for 3 weeks but egg media containing Tween $80(0.5 \%, \mathrm{w} / \mathrm{v})$ gave good growth. The organisms were non-photochromogenic and grew as rough colonies on egg media. Growth occurred at 28,37 and $45{ }^{\circ} \mathrm{C}$ but not at $52^{\circ} \mathrm{C}$.

Biochemical characteristics. The organisms did not grow on Sauton's agar containing $0.2 \%(\mathrm{w} / \mathrm{v})$ picric acid (the $\mathrm{pH}$ was adjusted to 7.0 ) or $0 . \mathrm{I} \%(\mathrm{w} / \mathrm{v}) \mathrm{NaNO}_{2}$. They did not utilize glucose, fructose, mannose, galactose, arabinose, xylose, rhamnose, trehalose, 


\section{Table I. Comparison of Mycobacterium shimoidei with known species of group III mycobacteria}

The symbols + and/or - give the properties of 'hypothetical median organisms' according to Liston, Wiebe \& Colwell (I963); R, rough colonies; S, smooth colonies. The following strains were used for preparation of the hypothetical median organisms: 26 strains of $M$. avium; 76 strains of $M$. intracellulare; 6 strains of $M$. xenopi; 94 strains of $M$. nonchromogenicum; i 5 strains of $M$. terrae; 2 I strains of $M$. triviale; 26 strains of $M$. novum; 8 strains of $M$. gastri; 7 strains of present isolate. Mycobacterium nonchromogenicum, $M$. terrae ( $M$. novum) and $M$. trivale showed similar characters in respect to the above and are presented as $M$. nonchromogenicum complex.

$$
\text { Character* }
$$

Colony morphology

Two week-arylsulphatase (A)

$\alpha$-Esterase (B)

Catalase (foam $>45 \mathrm{~mm})(\mathrm{C})$

Tween hydrolysis (I4 days) (D)

Resistance to $5 \mu \mathrm{g}$ ethambutol $/ \mathrm{ml}$ (E)

Resistance to $\mathrm{NH}_{2} \mathrm{OH} . \mathrm{HCl}(\mathrm{F})$

$0.25 \mathrm{mg} / \mathrm{ml}$

$0.5 \mathrm{mg} / \mathrm{ml}$

Glucose as C source (glutamate-N) (G)

Growth at $28^{\circ} \mathrm{C}$

Growth at $45^{\circ} \mathrm{C}$

Urease (H)

\begin{tabular}{|c|c|c|c|c|c|}
\hline $\begin{array}{c}M . \\
\text { avium }\end{array}$ & $\begin{array}{c}M . \\
\text { intra- } \\
\text { cellulare }\end{array}$ & $\begin{array}{c}M . \\
x e n o p i\end{array}$ & $\begin{array}{c}\text { Present } \\
\text { isolate } \\
(M . \\
\text { shimoidei })\end{array}$ & $\begin{array}{c}M . \\
\text { nonchro- } \\
\text { mogenicum } \\
\text { complex }\end{array}$ & $\begin{array}{c}M . \\
\text { gastri }\end{array}$ \\
\hline S & S & $S$ & $\mathrm{R}$ & $\mathrm{S} \uparrow$ & $S$ \\
\hline- & + & + & - & + & + \\
\hline+ & + & + & + & - & - \\
\hline- & - & - & - & + & + \\
\hline- & - & - & trace & + & + \\
\hline+ & + & + & - & - & - \\
\hline+ & + & - & - & + & - \\
\hline+ & + & - & - & + & - \\
\hline- & + & - & - & - & + \\
\hline+ & + & - & + & + & + \\
\hline+ & $+t$ & + & + & - & - \\
\hline- & - & - & - & - & + \\
\hline
\end{tabular}

* (A) Kubica \& Beam (I96I); (B) Käppler (I965); (C) Kubica et al. (I966); (D) Wayne, Doubek \& Russell (I964); (E) Mizuno, Toyama \& Tsukamura (1966), Tsukamura (I969); (F) Tsukamura (I965 b);

(G) Tsukamura \& Tsukamura (1967); (H) Bönicke (1962).

$\dagger$ Mycobacterium triviale shows rough colonies (R) rather than smooth colonies (S).

† Several strains of $M$. intracellulare do not grow at $45^{\circ} \mathrm{C}$.

inositol, mannitol, sorbitol, ethanol, $n$-propanol, $n$-butanol, iso-butanol, acetate, citrate, succinate, malate, pyruvate, benzoate, fumarate, malonate, and propylene glycol as sole sources of carbon in the presence of ammoniacal nitrogen. Glucose, fructose, acetate, succinate, malate, pyruvate and fumarate were not utilized as sources of carbon in the presence of glutamate-nitrogen. Glutamate was not utilized as a simultaneous source of carbon and nitrogen. They grew on Ogawa egg medium containing $0.5 \mathrm{mg} p$-nitrobenzoic acid $/ \mathrm{ml}$, Io $\mu \mathrm{g}$ thiophene-2-carboxylic acid hydrazide $/ \mathrm{ml}$ or $0.2 \%(\mathrm{w} / \mathrm{v})$ sodium $p$-aminosalicylate. They grew on Ogawa egg medium containing $0.125 \mathrm{mg} \mathrm{NH} \mathrm{N}_{2} \mathrm{OH}$. HCl/ml but not on this medium plus $0.25 \mathrm{mg} \mathrm{NH} \mathrm{NH}_{2} \mathrm{OHCl} / \mathrm{ml}$ or $5 \mu \mathrm{g}$ ethambutol $/ \mathrm{ml}$. The organisms were niacin-negative, two week-arylsulphatase activity-negative and $\alpha$ - and $\beta$-esterase-positive. Nicotinamidase and pyrazinamidase activities were variable; other amidase activities (Bönicke, 1962) were not shown. Nitrate was not reduced to nitrite.

Susceptibility to antituberculous agents. Strains 4I64, 4794, 4795, 4796, 7367 and 7380 were all resistant to $(\mu \mathrm{g} / \mathrm{ml})$ : streptomycin $(20)$, isoniazid $(0 \cdot \mathrm{I}), p$-aminosalicylate $(\mathrm{I} \cdot 0)$, ethionamide (40) and rifampicin (25); and were susceptible to $(\mu \mathrm{g} / \mathrm{ml})$ : ethambutol (5), kanamycin (I00) and capreomycin (100).

Lipid analysis. Analysis of strains 4796,7367 and 7380 for lipids did not reveal a specific lipid.

Seroagglutination. An antiserum against strain 4796, prepared according to the method of Schaefer (1965), was completely absorbed by strains 7367 and 7380 , indicating serological 
identity of the three strains. No other strain of group II or group III was agglutinated by this serum.

Slow growth, formation of non-photochromogenic colonies, negative nitrate reduction, and inability to grow on Sauton's agar containing $0.2 \%$ picric acid and $0.1 \% \mathrm{NaNO}_{2}$, are characters that place the test organisms in Runyon's (1959, I965) group III mycobacteria (Tsukamura, 1969). The organisms were compared with known species of group III, Mycobacterium avium Chester (I90 I), $M$. intracellulare Runyon (1967), M. xenopi Schwabacher (1959), $M$. nonchromogenicum Tsukamura (I965a), $M$. terrae Wayne (1966), $M$. triviale Kubica et al. (1970), M. novum Tsukamura (1967b), (a probable synonym of $M$. terrae Wayne), and M.gastri Wayne (1966) (Table I). The test organisms were differentiated from other known species by more than five characteristics. They are believed to constitute a new species with characters intermediate between the $M$. avium $/ M$. intracellulare complex and the $M$. nonchromogenicum complex. The name Mycobacterium shimoidei Tsukamura sp. nov. is proposed for the new species (type strain No. 4796, ATCC27962). The specific epithet was taken from the name of the second author who first isolated the strains.

We are grateful to Dr J. Marks for the systematic examination of this strain and to Dr P. A. Jenkins for the lipid analysis.

\section{REFERENCES}

BöNICKE, R. (1962). L'identification des mycobactéries à l'aide de méthodes biochimiques. Bulletin del'Union internationale contre la tuberculose 32, $13-76$.

Chester, F. D. (1901). In A Manual of Determinative Bacteriology, p. 356. New York: Macmillan. [Cited from Index Bergeyana (I966). Edited by R. S. Buchanan, J. G. Holt and E. F. Lessel, Jun. Baltimore: Williams \& Wilkins.]

KÄPPLER, W. ( I 965). Acetyl-Naphthylamin-Esterasen-Aktivität von Mykobakterien. Beiträge zur Klinik der Tuberkulose 130, I-4.

Kubica, G. P. \& BEAM, R. E. (196I). The arylsulfatase activity of acid-fast bacilli. II. The differentiation of Mycobacterium avium from the unclassified group III nonphotochromogenic mycobacteria. American Review of Respiratory Disease 83, 733-736.

Kubica, G. P., Jones, W. D., Abbott, V. D., Beam, R. E., Kilburn, J. O. \& Cater, J. C. (1966). Differential identification of mycobacteria. I. Tests on catalase activity. American Review of Respiratory Disease 94, 400-405.

Kubica, G. P., Silcox, V. A., Kilburn, J. O., Smithwick, R. W., Beam, R. E., Jones, W. D. \& StottMEIER, K. D. (1970). Differential identification of mycobacteria. VI. Mycobacterium triviale Kubica $s p$. nov. International Journal of Systematic Bacteriology 20, 16I-174.

Liston, J., Wiebe, W. \& Colwell, R. R. (I963). Quantitative approach to the study of bacterial species. Journal of Bacteriology 85, $106 \mathrm{I}-1070$.

Marks, J., Jenkins, P. A. \& SChaefer, W. B. (1971). Thin-layer chromatography of mycobacterial lipids as an aid to classification: technical improvement: Mycobacterium avium, $M$. intracellulare (Battey bacilli). Tubercle 52, 219-225.

Mizuno, S., Toyama, H. \& Tsukamura, M. (1966). Susceptibility of various mycobacteria to ethambutol. Differentiation between $M$. avium and M. terrae. Japanese Journal of Bacteriology 21, 672-674.

Runyon, E. H. (1959). Anonymous mycobacteria in pulmonary disease. Medical Clinics of North America 43, 273-290.

RunYon, E. H. (1965). Pathogenic mycobacteria. Advances in Tuberculosis Research 14, 235-287.

RunYon, E. H. (I967). Mycobacterium intracellulare. American Review of Respiratory Disease 95, 86I-865.

SCHAEFER, W. B. (1965). Serologic identification and classification of the atypical mycobacteria by their agglutination. American Review of Respiratory Disease 92, 85-93.

Schwabacher, H. ( I 959). A strain of Mycobacterium isolated from skin lesions of a cold-blooded animal, Xenopus laevis, and its relation to atypical acid-fast bacilli occurring in man. Journal of Hygiene 57, $57-67$. 
TsuKamura, M. (I962). Differentiation of Mycobacterium tuberculosis by sodium salicylate susceptibility. American Review of Respiratory Disease 86, 8I-83.

Tsukamura, M. (I565a). A group of mycobacteria from soil sources resembling nonphotochromogens (group III). A description of Mycobacterium nonchromogenicum. Medicine and Biology (Tokyo) 7r, I IO-I I3.

Tsukamura, M. ( $1965 b)$. Differentiation of mycobacteria by susceptibility to hydroxylamine and 8-azaguanine. Journal of Bacteriology 9o, 556-557.

Tsúkamura, M. (I967a). Identification of mycobacteria. Tubercle 48, 3 I I-338.

Tsúkamura, M. (1967 b). Two types of slowly growing, nonphotochromogenic mycobacteria obtained from soil by the mouse passage method: Mycobacterium terrae and Mycobacterium novum. Japanese Journal of Microbiology 11, 163-172.

Tsukamura, M. (I 969). Identification of group II scotochromogens and group III nonphotochromogens of mycobacteria. Tubercle 50, $5 \mathrm{I}-60$.

Tsukamura, M. \& Tsukamura, S. ( I964). Differentiation of Mycobacterium tuberculosis and Mycobacterium bovis by $p$-nitrobenzoic acid susceptibility. Tubercle $45,64-65$.

Tsukamura, M. \& Tsukamura, S. (1967). A comparative study of carbon source requirements of $M y c o$ bacterium avium, group II scotochromogens, group III nonphotochromogens, and Mycobacterium terrae in the presence of glutamate-nitrogen. American Review of Respiratory Disease 96, 5I 2-5I 6.

WAYNE, L. G. (I966). Classification and identification of mycobacteria. III. Species within group III. American Review of Respiratory Disease 93, 919-928.

Wayne, L. G., Doubek, J. R. \& Russell, R. L. (I964). Classification and identification of mycobacteria. I. Tests employing Tween 80 as substrate. American Review of Respiratory Disease 90, 588-597. 